\title{
DAERAH SALJU YANG "DINGIN" Tinjauan terhadap Novel Daerah Salju Karya Kawabata Yasunari
}

\author{
Fajria Noviana \\ Fakultas Ilmu Budaya Universitas Diponegoro \\ Email: fajria_noviana@yahoo.com
}

\begin{abstract}
Expressive approach on this novel was conducted to proof scholars' opinions about the themes that Kawabata often used in his works, which affected by his unpleasant childhood. Those themes are loneliness, emptiness, broken heart, sexuality, and others in common. Comparative study was also conducted but to find out how this novel affected by other literary works and Japanese traditions, and vice versa.
\end{abstract}

Keywords: expressive approach, comparative study, themes, Japanese traditions

\section{PENDAhULUAN}

Kawabata Yasunari lahir pada tahun 1899 dalam keluarga yang cukup berada di Osaka. Ayahnya, Kawabata Eikichi, adalah seorang dokter terkemuka yang meninggal karena TBC saat Yasunari baru berusia dua tahun. Saat menginjak usia tiga tahun ibunya meninggal, dan saat ia berusia tujuh tahun neneknya juga meninggal, disusul oleh kakak perempuan satu-satunya saat ia berusia sembilan tahun. Kematian keluarganya yang beruntun ini membuat ia kehilangan masa kanak-kanak yang normal, sampai-sampai pada saat ia tumbuh dewasa ia acapkali mengatakan bahwa ia telah belajar tentang kesendirian dan "ketiadaan akar" di waktu dini.

Kawabata menggambarkan dirinya sendiri sebagai seorang anak yang tidak memiliki rumah maupun keluarga. Beberapa kritikus beranggapan bahwa trauma dini yang dialaminya telah melatarbelakangi rasa kehilangan dan penyesalan yang banyak ditemui dalam karya-karyanya. Karya-karya Kawabata sering digambarkan sebagai mengekspresikan perasaan tertekan dan sering mengeksplorasi tempat keberadaan seks dalam kebudayaan dan dalam kehidupan individual.

Pada tahun 1968, Kawabata Yasunari menjadi novelis Jepang pertama yang memenangkan hadiah Nobel di bidang sastra. Ia mengutuk tindakan bunuh diri dalam pidato penerimaan Nobel-nya, mungkin karena beberapa temannya telah melakukannya. Namun, setelah didera kondisi kesehatan yang buruk dalam kurun waktu yang cukup lama, Kawabata mengakhiri hidupnya dengan meracun diri menggunakan gas pada 16 April 1972, dua tahun setelah Mishima Yukio yang menjadi sahabat dekatnya mengakhiri hidup dengan bunuh diri. Banyak teori telah dikemukakan tentang penyebab Kawabata melakukan bunuh diri, antara lain kesehatannya yang buruk, kemungkinan hubungan cinta gelap, atau keterkejutan yang disebabkan oleh kematian Mishima Yukio. Namun, berbeda dengan Mishima, Kawabata tidak meninggalkan catatan apapun, dan karena ia tidak pernah membahasnya secara sungguh-sungguh dalam tulisan-tulisannya, maka motifnya tetap tidak jelas.

Kawabata sebenarnya pada awalnya tidak menulis Daerah Salju sebagai sebuah novel, tetapi sebagai beberapa cerita pendek yang dimuat dalam beberapa majalah selama kurun waktu duabelas tahun (1935-1947). Semua cerita pendek itu, setelah disesuaikan di beberapa bagian, kemudian digabungkan menjadi satu dengan judul Yukiguni dan diterbitkan pada tahun 1937. Namun karena Kawabata masih menambahkan lagi dua cerita pendek ke dalam gabungan cerita pendek ini pada tahun 1940 dan 1941, maka Yukiguni versi yang beredar sekarang ini baru terbit secara utuh pada tahun 1947.

Kisah dalam novel Daerah Salju ini berlatar tempat di Yuzawa, daerah yang terkenal dengan pemandian mata air panasnya. Yuzawa 
terletak di Prefektur Niigata di sebelah utara pulau Honshu yang selama musim dingin selalu tertutup salju. Meskipun sebenarnya tidak disebutkan secara jelas dalam novel, tetapi oleh banyak pengamat diyakini bahwa memang daerah Yuzawa-lah yang menjadi latar tempat novel ini.

\section{LANDASAN TEORI}

\subsection{Sastra Bandingan}

Sastra bandingan adalah pendekatan dalam ilmu sastra yang tidak menghasilkan teori tersendiri. Dapat dikatakan bahwa teori apa pun bisa digunakan dalam penelitian sastra bandingan. Dalam langkah-langkah kerja penelitiannya, metode perbandingan atau komparasi menjadi metode yang utama. Dengan demikian, analisisnya berlandaskan azas banding-membandingkan (Damono, 2009: 1).

Sastra bandingan merupakan kajian sastra di luar batas sebuah negara dan kajian tentang hubungan antara sastra dengan bidang ilmu lain seperti seni, filsafat, ilmu sosial, dan lain-lain (Remak melalui Stallknet dan Frenz, 1990: 1). Secara singkat, dapat dikatakan bahwa sastra bandingan membandingkan sastra sebuah negara dengan sastra negara lain serta membandingkan sastra dengan bidang lain.

Menurut Remak, unsur-unsur yang terdapat dalam sastra bandingan adalah unsur ruang, waktu, kualitas, dan intensitas (melalui Stallknecht dan Frenz, 1990: 7). Dilihat dari unsur waktu, sastra bandingan dapat membandingkan dua atau lebih karya sastra dari periode yang berbeda. Sementara jika dilihat dari unsur tempat, maka sastra bandingan akan membandingkan dua atau lebih karya sastra yang berbeda menurut wilayah geografis (Endraswara, 2008: 128-134). Oleh karena itu, kajian sastra bandingan tidak dapat mengabaikan peranan sastra nasional ${ }^{1}$ yang lama-kelamaan dapat menjadi sastra dunia ${ }^{2}$. Hal

\footnotetext{
${ }^{1}$ Sastra nasional adalah sastra yang secara umum menjadi milik suatu bangsa yang dibatasi oleh wilayah politik suatu negara (lihat Endraswara, 2008: 134)

2 Sastra dunia adalah sastra yang memuat pandangan-pandangan universal yang diakui oleh orang-orang seluruh dunia (lihat Endraswara, 2008: 134). Biasanya karyakarya semacam ini tergolong sebagai mahakarya atau ditulis oleh penulis kelas dunia (Barat) dan diterjemahkan ke dalam
}

ini menunjukkan bahwa konsep sastra bandingan sangat luas. Bahkan pada perkembangan selanjutnya, konteks sastra bandingan tertuju pada pembandingan sastra dengan nonsastra. Pembandingan seperti ini ditujukan untuk mencari keterkaitan antar aspek kehidupan.

Dilihat dari unsur kualitas, karya yang dipilih untuk dibandingkan dalam studi sastra bandingan tidak harus merupakan karya yang diakui mutunya, baik secara nasional apalagi internasional. Sementara jika dilihat dari unsur intensitas, karya yang dipilih untuk dibandingkan dapat berupa karya sastra yang belum terkenal. Kedua unsur ini menguntungkan penulis-penulis baru yang belum diakui dunia, karena mereka dan atau karya-karya mereka yang dijadikan sebagai bahan kajian suatu saat dapat naik ke dalam lingkup sastra dunia. Meskipun demikian, kedua aspek ini seringkali dihindari oleh peneliti sastra bandingan, terutama pada aspek intensitas karena peneliti cenderung untuk membandingkan karya sastrakarya sastra yang sudah dikenal oleh masyarakat luas.

Unsur-unsur ruang, waktu, kualitas, dan intensitas memberikan perbedaan antara sastra bandingan dengan sastra dunia. Selain itu, terdapat hal lain yang harus diperhatikan, yaitu konsep sastra bandingan Amerika dan Prancis. Konsep sastra bandingan Amerika menekankan pada hubungan sastra dengan disiplin lain yang tidak terdapat pada sastra dunia, sedangkan konsep sastra bandingan Prancis menekankan pada cara pembandingan yang juga tidak terdapat pada sastra dunia.

Di luar masalah konsep, dalam penelitian sastra bandingan sebenarnya terdapat lima pendekatan yang dapat digunakan (Clements melalui Damono, 2009: 6), yaitu:

1. Tema/mitos

2. Genre/bentuk

3. Gerakan/zaman

4. Hubungan-hubungan antara sastra dan bidang seni dan disiplin ilmu lain

5. Pelibatan sastra sebagai bahan bagi perkembangan teori yang terus-menerus bergulir berbagai bahasa (lihat Remak melalui Stallknecht dan Frenz, 1990: 7) 


\subsection{Pendekatan Ekspresif}

Wilayah studi pendekatan ini adalah diri pengarang, pikiran dan perasaan, dan hasil-hasil karyanya. Pendekatan ini dapat dimanfaatkan untuk menggali ciri-ciri individualisme, nasionalisme, komunisme, feminisme, dan sebagainya dalam karya, baik karya sastra individual maupun karya sastra dalam kerangka periodisasi.

Menurut Abrams (1958: 22) pendekatan ekspresif ini menempatkan karya sastra sebagai curahan, ucapan, dan proyeksi pikiran dan perasaan pengarang. Pengarang sendiri menjadi pokok yang melahirkan produksi persepsipersepsi, pikiran-pikiran, dan perasaan-perasaan yang dikombinasikan. Praktik analisis dengan pendekatan ini mengarah pada penelusuran kesejatian visi pribadi pengarang yang dalam paham struktur genetik disebut dengan pandangan dunia. Seringkali pendekatan ini mencari fakta-fakta tentang watak khusus dan pengalaman-pengalaman sastrawan yang secara sadar atau tidak telah membukakan dirinya dalam karyanya tersebut.

Dengan demikian, secara konseptual dan metodologis dapat diketahui bahwa pendekatan ekspresif menempatkan karya sastra sebagai: (1) wujud ekspresi pengarang, (2) produk imajinasi pengarang yang bekerja dengan persepsi-persepsi, pikiran-pikiran dan perasaan-perasaannya, dan (3) produk pandangan dunia pengarang.

Secara metodis, langkah kerja yang dapat dilakukan melalui pendekatan ini adalah: (1) memerikan sejumalah pikiran, persepsi, dan perasaan pengarang yang hadir secara langsung atau tidak di dalam karyanya, (2) memetakan sejumlah pikiran, persepsi, dan perasaan pengarang yang ditemukan dalam karyanya ke dalam beberapa kategori faktual teks berupa watak, pengalaman, dan ideologi pengarang, (3) merujukkan data yang diperoleh pada tahap (1) dan (2) ke dalam fakat-fakta khusus menyangkut watak, pengalaman hidup, dan ideologi pengarang secara faktual luar teks (data sekunder berupa data biografis), dan (4) membicarakan secara menyeluruh, sesuai tujuan, pandangan dunia pengarang dalam konteks individual maupun sosial dengan mempertimbangkan hubungan-hubungan teks karya sastra hasil ciptaannya dengan data biografisnya.

\section{PEMBAHASAN}

Membaca novel Daerah Salju ini mengingatkan akan novel Kawabata yang lain, yaitu Izu no Odoriko, novel pertama Kawabata yang mendapat pujian dari para kritikus sastra. Dalam kedua novel ini, tokoh utama laki-laki yang sedang melakukan perjalanan dan tokoh utama perempuan, seorang geisha muda, merasa saling jatuh cinta. Namun pada akhirnya kedua belah pihak, baik laki-laki maupun perempuan, harus merasakan kekecewaan karena hubungan cinta mereka tidak berakhir bahagia.

Berikut ini adalah beberapa hal yang berkaitan dengan pendekatan ekspresif dan pendekatan dengan sastra bandingan yang ada dalam novel ini berikut penjelasannya.

\subsection{Kesalahkaprahan Pemahaman tentang Geisha}

Jika ditinjau dari aksara kanjinya, yaitu 芸 yang berarti seni dan 者 yang berarti orang, maka secara harfiah geisha berarti orang dalam bidang seni. Begitu juga dengan arti geisha yang sebenarnya, yaitu orang, selalu berjenis kelamin perempuan, yang menggunakan keterampilan yang dimilikinya di bidang seni untuk menghibur orang lain.

Profesi geisha dalam budaya tradisional Jepang sendiri sebenarnya seperti yang dijelaskan secara singkat di atas. Namun, selain itu terdapat juga geisha, khususnya yang ada di sekitar onsen sebagai daerah wisata sehingga mendapat sebutan onsen geisha, yang tidak terlalu menghiraukan kadar keterampilannya di bidang seni tetapi justru lebih memfokuskan dirinya untuk menemani dan menghibur para tamu lelaki secara seksual. Dalam novel yang berlatar tempat daerah wisata dengan onsen ini, profesi geisha yang ada adalah onsen geisha, meskipun kadangkadang juga menghibur para tamu dengan tarian, nyanyian, dan permainan shamisen, meskipun tidak terlalu mahir.

...yang ada hanya geisha yang agak lanjut usia yang tidak mau berdiri untuk menari...

$$
\text { (hal.35) }
$$

Kutipan ini dapat diartikan bahwa geisha yang agak lanjut usia tersebut kemungkinan sudah tidak ingin menghibur tamu dengan menari, menyanyi, atau memetik shamisen lagi. Ia, dan mungkin geisha yang lain, 
hanya menyediakan "hiburan" secara seksual.

...ia memasang telinga pada suara shamisen yang datang dari ruang perjamuan...

"Mungkin dia Fumi-chan di Izutsu-ya. Saya paling mudah mengenali yang paling pandai dan yang paling kaku." "Adakah yang pandai memetiknya?"

"Anak yang bernama Komako, meskipun masih muda, belakangan ini sudah maju."

$$
\text { (hal.81-83) }
$$

Kutipan ini jelas menunjukkan bahwa kemampuan memetik shamisen para geisha yang ada dalam novel ini tidak begitu baik, bahkan ada juga yang sangat kaku.

Meskipun demikian, masih ada juga geisha yang memfokuskan dirinya untuk menghibur para tamu dengan keterampilannya di bidang seni, walaupun pada akhirnya juga bersedia melayani secara seksual seperti kutipan berikut.

...tapi ada kemungkinan gadis yang tinggal bersama guru tari akan datang setelah mempertunjukkan dua-tiga macam tarian walau sebenarnya ia pun diminta juga membantu perjamuan itu.

(hal.35)

...kalau seorang geisha berlatih bersungguh-sungguh dengan mempergunakan not musik di daerah pegunungan terpencil ini...

"Untuk melayani tamu, yang utama tarian..."

"...Saya bisa juga menyanyikan, walaupun tidak pandai, lagu-lagu yang saya dengar ketika berlatih menari..."

Tiba-tiba suasana penuh rangsang berahi. ...

Sejak itu, walau ada Komako menginap, tapi tidak lagi dia memaksakan diri untuk pulang sebelum fajar menyingsing.

(hal.94-100)

\subsection{Pelecehan Perempuan}

$\begin{array}{lll}\text { Pelecehan perempuan di sini } & \text { sebagai aktivitas } & \text { yang } \\ \text { diartikan sebai }\end{array}$ merendahkan martabat perempuan. Pelecehan ini dilakukan oleh Shimamura terhadap istrinya dan Komako. Shimamura yang sudah memiliki istri dan anak dengan sengaja menjalin hubungan gelap dengan seorang geisha, yaitu Komako. Hubungan gelap ini tidak hanya sebatas pada rasa cinta belaka, tetapi juga sudah sampai ke tahap berhubungan badan.

Sementara saat Komako sudah memberikan cintanya kepada Shimamura, Shimamura justru mengkhianatinya dengan memiliki ketertarikan pada Yoko, baik secara batiniah maupun lahiriah. Selain itu, Shimamura pun mengucapkan kata-kata yang memberi kesan bahwa nilai perempuan itu hanya terletak pada keindahan bentuk tubuhnya dan perempuan hanya dianggap sebagai objek pemuas nafsu laki-laki belaka.

"Tolol! Mungkin orang biasanya hanya meraba yang sebelah saja."...

"Lain kali bilang supaya merata pada kedua-duanya."

(hal.134-135)

\subsection{Penggunaan Kaca atau Cermin}

Dalam novel ini, kaca atau cermin memainkan peranan penting untuk menggambarkan sesuatu dalam beberapa adegan. Shimamura pertama kali melihat Yoko, perempuan dalam kereta yang akhirnya membuat ia jatuh hati, melalui kaca jendela kereta yang berubah menjadi seperti cermin. Komako, Yoko, dan alam diceritakan menyatu juga melalui cermin.

Kesan Shimamura terhadap Yoko saat ia melihatnya untuk pertama kalinya melalui kaca jendela kereta yang berubah menjadi seperti cermin itu begitu mendalam, sehingga ia berkali-kali menggambarkan peristiwa di dalam kereta itu dalam berbagai kesempatan.

...lalu ketika dengan kebetulan dibuatnya garis pada kaca jendela, maka muncullah di situ mata seorang wanita. Dia terkejut sehingga hampir terpekik. ...

Masih terpantul wajah Yoko yang cantik dan Shimamura menemukan sesuatu yang dingin dan jernih pada gadis itu...

(hal.23-26)

...ia sendiri memandang wanita itu bukan sebagai sesuatu yang nyata, tepat seperti wanita yang terbayang pada kaca kereta api senja.

(hal.42) 
Ketika ia tadi pagi melihat Komako dalam cermin yang membayangkan salju di gunung, memang ia teringat akan gadis yang terbayang pada kaca jendela kereta api senja...

...hitam mata gadis itu yang menjadi agak terang ketika bertumpang tindih dengan api di ladang...di balik wajahnya yang ditatapi Shimamura pada kaca jendela kereta api.

(hal.74-79)

Shimamura berdebar lagi teringat akan saat ia melihat api menyala di tengah wajah Yoko di dalam kereta api...

(hal.218)

Mata adalah bagian tubuh yang paling banyak muncul dalam karya sastra, terutama dalam puisi cinta dimana selama berabad-abad diakui bahwa cinta datang melalui mata, seperti ungkapan 'dari mata turun ke hati', dan seringkali mengandung arti kiasan. Mata juga dikatakan mampu mengekspresikan pikiran dan perasaan. Pada kutipan halaman 23-26 di atas, disebutkan tentang bayangan mata di kaca jendela kereta yang membuat Shimamura terkejut. Hal ini dapat dihubungkan dengan mata yang muncul dalam Kumo no Ito karya Akutagawa Ryūnosuke tahun 1918. Mata dalam novel Kumo no Ito adalah mata Sang Buddha yang mengawasi segala tindaktanduk manusia, khususnya yang sedang menjalani hukuman di neraka. Dalam novel ini, mata itu muncul saat Shimamura sedang asyik memandangi Yoko yang membuatnya merasa bersalah, sehingga seakan-akan mata itu sedang mengawasi tingkah laku Shimamura.

Kesan Shimamura saat melihat pantulan wajah Komako di cermin dan pantulan wajah Yoko di kaca jendela kereta seperti menyatu dengan pemandangan alam di balik kaca juga sangat mendalam, sehingga ia juga berkali-kali menggambarkan hal itu dalam berbagai kesempatan.

Apalagi tokoh itu hampa seperti bening dan pemandangannya adalah aliran gelap malam yang samar-samar dan keduanya bersatu padu...

Terutama ketika ada api menyala di ladang nampak tepat di tengah-tengah wajah gadis itu...

(hal.23-26)
Yang berkilauan putih di dalam kaca ialah salju. Dan di dalam salju itu kelihatan terapung pipi wanita yang merah itu.

(hal.69)

...melihat keindahan yang tak terkatakan yang disebabkan oleh hitam mata gadis itu yang menjadi agak terang ketika bertumpang tindih dengan api di ladang dan gunung yang terus mengalir di balik bayangan wajahnya yang ditatapi Shimamura pada kaca jendela kereta api. ...ia pun teringat akan merah pipi Komako yang terbayang terapung di dalam salju yang memenuhi cermin.

(hal.79)

Shimamura berdebar lagi teringat akan saat ia melihat api menyala di tengah wajah Yoko di dalam kereta api...

(hal.218)

Simbolisme cermin tidak hanya bergantung pada apa yang menyebabkan pantulan bayangan di dalamnya, tetapi juga pada yang dilihat seseorang di dalam cermin itu, entah itu diri sendiri, kebenaran, hal yang diidam-idamkan, atau ilusi. Gagasan di waktu lampau bahwa seni itu merupakan tiruan alam pada akhirnya seringkali dianalogikan dengan sebuah cermin. Cermin menjadi analogi yang umum digunakan dalam teori estetika neo-klasik, berdasarkan pada gagasan bahwa seni itu merupakan tiruan alam. Banyak dongeng dan cerita yang menggunakan cermin ajaib, misalnya bola kaca (kristal) Merlin si penyihir yang bisa memperlihatkan segala hal di dunia yang ingin dilihat dan cermin ajaib milik ibu tiri Snow White yang merupakan gabungan dari piranti magis dan piranti kesombongan duniawi.

Pada kenyataannya, cermin banyak dipasang dalam jinja sebagai simbol kehadiran kami di sana sehingga keberadaan cermin dalam jinja tersebut sangat penting. Kami, yang direpresentasikan ke dalam wujud cermin, adalah sesuatu yang murni. Demikian juga dengan cermin dalam novel ini yang seolah-olah merefleksikan sesuatu ke dalam bentuk yang lebih murni. 
3.4 Makna yang Tersirat dalam Beberapa Adegan

Terowongan panjang yang muncul dalam kalimat pertama novel ini merupakan "pintu gerbang" untuk masuk ke "dunia yang tidak nyata", yaitu tempat tinggal Komako, kekasih gelap Shimamura.

Begitu keluar dari terowongan panjang di perbatasan, tibalah di daerah salju. Dasar malam menjadi putih.

(hal.19)

Ketika keluar dari terowongan panjang setelah naik di gunung daerah perbatasan... Di sebelah sini belum ada salju.

(hal.112-113)

Kutipan kedua menunjukkan belum turunnya salju di luar daerah salju yang dibatasi oleh pegunungan dengan terowongan panjang tersebut. Di sini Kawabata seakan-akan ingin menegaskan bahwa daerah salju benar-benar merupakan "dunia yang tidak nyata".

Kehidupan Shimamura di Tokyo yang monoton dan hampa telah mengubahnya menjadi seseorang yang sukar untuk melihat ketulusan dan keindahan dari apa yang ada di sekelilingnya. Namun, kemonotonan dan kehampaan hidupnya untuk sementara terisi dengan kehadiran Komako meski dalam "dunia yang tidak nyata".

...bahwa Komako menjadi geisha untuk kepentingan tunangannya pun..., sehingga Shimamura tidak bisa percaya.

$$
\text { (hal.84) }
$$

Kamar Komako yang baru saja ditinggalkannya, juga merupakan suatu dunia yang jauh.

(hal.80)

Komako rela menjual tubuhnya untuk mencari uang guna membantu meringankan biaya perawatan penyakit Yukio, meskipun ia tahu bahwa pada akhirnya Yukio tidak akan dapat sembuh dari penyakitnya itu. Sementara, Yoko menghabiskan waktunya untuk merawat Yukio dengan tulus. Shimamura menyadari bahwa usaha Komako dan Yoko untuk mengobati dan merawat Yukio itu bukanlah suatu usaha yang sia-sia, karena cinta adalah suatu hal yang murni dan bukan kesia-siaan, meskipun pada akhirnya Yukio meninggal karena penyakitnya.

"... Ada gadis yang menemaninya yang merawatnya dengan sepenuh hati, ...Ia seperti ibunya, ..."

(hal.74)

Kalau bertemu dengan Komako nanti, ia mau menuduhnya sia-sia, tapi malah terasa padanya kehadiran wanita itu menjadi lebih murni lagi.

(hal.84)

\subsection{Kebekuan Hati Tokoh Utama}

Komako adalah seorang geisha muda yang memahami betul peraturan yang harus ditaati oleh para geisha, yaitu tidak boleh memiliki perasaan dengan pelanggannya. Hubungan yang ada antara ia dan pelanggannya hanya berupa hubungan bisnis belaka. Akan tetapi, ia mendobrak peraturan ini dengan mencoba mencintai Shimamura, walaupun pada akhirnya ia menyadari bahwa perasaan cinta tersebut hanya semu.

...itu suara wanita dari dasar hatinya terhadap laki-laki miliknya.

(hal.53)

Rasa cinta Komako memang terarah kepada diri Shimamura, namun ada semacam kehampaan di dalam dirinya yang membuatnya menganggap hal itu sebagai usaha sia-sia...

(hal.162)

Begitu pula halnya dengan Shimamura. Ia yang telah lama merasakan kehampaan dalam hidupnya berusaha untuk mengisinya dengan mencoba mencintai Komako dan Yoko.

Sementara Shimamura merasa hampa dan sedih, masuklah Komako, bagaikan terpasang lampu yang hangat.

(hal.85)

Terasa olehnya bahwa Yoko mempunyai pandangan mata yang bagaikan cahaya..., sehingga Shimamura tertarik juga kepada gadis itu.

(hal.162) 
Namun pada akhirnya ia pun ternyata tidak bisa mencintai orang lain dengan setulus hati. Kehidupannya di kota besar seperti Tokyo, kelihatannya telah membuatnya kehilangan rasa itu, seperti pada kutipan tentang rasa cinta Komako kepada Shimamura pada halaman 162.

\section{SIMPULAN}

Novel ini cukup banyak menyinggung seksualitas, yang menjadi salah satu pembuktian akan seringnya Kawabata mengeksplorasi tempat keberadaan seks dalam kebudayaan dan dalam kehidupan individual melalui karyakaryanya.

Penggunaan salju yang merupakan simbolisasi dari rasa dingin dan kesuraman, sangat sesuai dengan apa yang dirasakan oleh Shimamura dan Komako saat mereka bertemu di daerah bersalju itu. Ketidakpuasan Shimamura terhadap kehidupannya dan ketidakberuntungan hidup Komako telah menggiring mereka pada kehidupan yang suram. Meskipun cerita diakhiri dengan open ending, dimana tidak disebutkan dengan jelas bagaimana akhir hubungan gelap mereka, tetapi sepertinya Kawabata sudah mengisyaratkan tentang ketidakbahagiaan atau kehampaan, baik dalam percintaan maupun dalam kehidupan mereka berdua. Seperti juga dengan dimatikannya tokoh Yoko untuk lebih menegaskan ketidakbahagiaan kehidupan percintaan Shimura yang diam-diam mulai jatuh hati padanya. Mungkin juga Kawabata memilih mematikan tokoh Yoko karena tokoh ini tidak mewakili tipikal onsen geisha dan mungkin karena tokoh ini adalah orang ketiga dalam hubungan percintaan semu Shimamura dan Komako. Selain itu, dengan dimatikannya tokoh Yoko, Kawabata seakan-akan ingin mengatakan bahwa cinta segitiga tidak akan pernah berakhir bahagia. Maka, pemilihan kata "daerah salju" sebagai judul novel ini sangat sesuai untuk menggambarkan dinginnya hati yang dirasakan oleh tokoh-tokoh dalam novel ini.

Melihat hal tersebut di atas, sepertinya tema kesendirian atau rasa sepi, kehampaan, dan kasih tak sampai adalah tema yang berusaha diangkat oleh Kawabata dalam novel ini. Kesendirian dan kehampaan tergambar dalam diri Komako dan Shimamura. Cinta Shimamura pada Komako dan Yoko pun tidak berakhir bahagia. Hal ini pun juga menjadi salah satu pembuktian akan jenis tema yang acap muncul dalam karya-karya Kawabata, yang digambarkan sebagai mengekspresikan perasaan tertekan dan rasa kehilangan serta penyesalan.

\section{DAFTAR PUSTAKA}

Abrams, M.H. 1958. The Mirror and Lamp: Romantic Theory and the Critical Tradition. New York: The Norton Library; W.W. Norton \& Company Inc.

Damono, Sapardi Djoko. 2009. Sastra Bandingan. Jakarta: Editum.

Ferber, Michael. 2007. A Dictionary of Literary Symbols. New York: Cambridge University Press.

Fukuda, Kiyoto. 1990. Kawabata Yasunari, Hito to Sakuhin. Tokyo: Shimizu Shoin.

Kawabata, Yasunari. 1987. Daerah Salju. Terjemahan oleh Matsuoka Kunio dan Ajip Rosidi. Jakarta: PT Dunia Pustaka Jaya.

Nurgiyantoro, Burhan. 2002. Teori Pengkajian Fiksi. Yogyakarta: Gadjah Mada University Press.

Ratna, Nyoman Kutha. 2004. Teori, Metode, dan Teknik Penelitian Sastra. Yogyakarta: Pustaka Pelajar.

Stallknecht, Newton P. dan Frenz, Horst (ed). 1990. Sastera Perbandingan, Kaedah dan Perspektif. Kuala Lumpur: Dewan Bahasa dan Pustaka Kementerian Pendidikan Malaysia.

http://www.kirjasto.sci.fi/kawabata.htm 